\title{
Interaction among Nutritive, Textural, and Sensory Properties of Rabbit Sausages
}

\author{
Joseph M. Wambui, ${ }^{1}$ Edward G. Karuri, ${ }^{1}$ and Margaret M. M. Wanyoike ${ }^{2}$ \\ ${ }^{1}$ Department of Food Science, Nutrition and Technology, University of Nairobi, Nairobi 29053-00625, Kenya \\ ${ }^{2}$ Department of Animal Production, University of Nairobi, Nairobi 29053-00625, Kenya \\ Correspondence should be addressed to Joseph M. Wambui; mwanikem@yahoo.com
}

Received 28 April 2016; Revised 19 July 2016; Accepted 7 August 2016

Academic Editor: Raquel P. Guiné

Copyright (c) 2016 Joseph M. Wambui et al. This is an open access article distributed under the Creative Commons Attribution License, which permits unrestricted use, distribution, and reproduction in any medium, provided the original work is properly cited.

\begin{abstract}
The nutritive, textural, and sensory properties of commercial fresh rabbit sausages and their interactions were evaluated. The mean contents of moisture, protein, fat, ash, and carbohydrate were $43.89 \pm 1.66 \%, 9.82 \pm 2.71 \%, 22.37 \pm 1.7 \%, 2.99 \pm 0.10 \%$, and $20.94 \pm$ $3.05 \%$, respectively. Conversely, the mean values of hardness, adhesiveness, springiness, cohesiveness, gumminess, and chewiness were $103.36 \pm 3.48 \mathrm{~N},-4.54 \pm 1.58 \mathrm{~N} \mathrm{~s}, 3.38 \pm 0.67 \mathrm{~mm}, 0.15 \pm 0.03,16.07 \pm 3.20 \mathrm{~N}$, and $55.73 \pm 20.44 \mathrm{~N} \mathrm{~mm}$, respectively. The moisture and protein contents showed significant negative correlation while three remaining nutritive properties showed significant positive correlation with textural properties $(P<0.05$ for all parameters). The score for nonparametric ranking of sensory properties like appearance/colour, flavour, juiciness, and tenderness ranged from 28.28 to $38.78,29.41$ to $35.91,30.06$ to $37.38,26.75$ to 40.69 , and 29.03 to 36.75 , respectively. In conclusion, rabbit sausages formulated with low quantities of moisture and protein result in hard sausages with low acceptability by sensory panellist. To improve the sausages, it is recommended that processors develop an optimal formulation.
\end{abstract}

\section{Introduction}

The exponential growth of human population in developing nations has stimulated the demand for meat. In 2006, it was estimated that there would be a deficit of red meat from cattle, camel, and sheep by 2016 [1]. This corresponds with global projections whereby, by 2020 , meat consumption by developing nations is expected to expand from $52 \%$ currently to $63 \%$ of total meat consumption worldwide [2]. Owing to their rapid reproduction, rabbits have the potential to offer the much-needed alternative source of proteins and meet the anticipated deficits. Domesticated rabbits can therefore be used as an alternative source of dietary protein these nations [3].

Despite of the potential, only a few meat processors have focused on introducing processed rabbit meat products for the consumers [4]. The processed rabbit meat products (e.g., meat patties and sausages) available currently are made from coarsely ground meat [5]. Traditional coarse-ground sausages manufactured from rabbit meat have not gained much interest in marketplace [5]. As a result, the demand for the meat continues to be low [6]. Value addition to the rabbit meat products not only provides the much-needed nutritional components, but can increase consumer convenience through decreasing preparation time, minimising preparation steps, and eliminating risks from the kitchen $[7,8]$. Some of the risks include introduction of bones to food during preparation because rabbit bones tend to produce bone fragments more easily if compared with pork, beef, and poultry [5].

Introduction and success of novel rabbit meat products bring new challenges for meat processors because of more dynamic, complex, and differentiated demands of modern consumer along with emphasis on quality foods that are rich in sensory and organoleptic properties and also convenient $[9,10]$. Flavour and colour changes are important organoleptic factors for the success of processed meat products [7]. The effect of processing meat products from other species on some of the above-mentioned properties has been investigated in detail [11-14]. However, despite the understanding 
of the influence of rabbit meat processing on some of these properties, there is a paucity of studies that have investigated this topic in detail $[4,5]$.

In novel meat product processing, optimum utilisation of several protein sources of animal origin require information on their relevant functional properties. This serves several purposes. Firstly, it provides greater flexibility in choice of raw material. Secondly, it facilitates modern meat processing. Finally, it supports designing of mathematical model-based formulations. All these ensure optimum function, flavour, and nutritional balance. Therefore, the present study was aimed at understanding the interactions of nutritional, textural, and sensory properties in rabbit sausages for optimum utilisation of rabbit meat in novel meat products.

\section{Materials and Methods}

2.1. Sample Collection. The fresh rabbit sausage samples were collected twice a week in two alternative weeks from a rabbit meat products retail outlet in Kiambu County, Kenya. The sausages were obtained from the sole producer in the region. On each day, four packets containing eight sausages each were purchased. To ensure uniformity of samples, samples from the same day had similar batch numbers. However, samples from different days were from different batches. Therefore, samples differed from each other depending on the day sampled. Samples were immediately transported to the analytical laboratory by placing them in an ice-box and stored at $4^{\circ} \mathrm{C}$ until further analysis. From each sampling day, two sausages from each packet were randomly selected and were analysed for nutritional, textural, or sensory properties.

2.2. Sample Description. The information on the ingredients used to process the sausages was obtained directly from the processor. These included rabbit meat (55-60\%), water (7$10 \%)$, vegetable oil (15-20\%), rusk (2-7\%), cornstarch (5\%), salt $(2-5 \%)$, and permitted food colour and preservatives (1\%). The length and diameter of the raw sausages were approximately $10 \mathrm{~cm}$ long and $2.5 \mathrm{~cm}$, respectively.

2.3. Nutritional Property Analysis. The sausages temperature was allowed to equilibrate at room temperature $\left(23^{\circ} \mathrm{C}\right)$ for $4 \mathrm{~h}$ and subsequently they were heated in boiling water for $5 \mathrm{~min}$ [15]. The nutritional properties and moisture, protein, fat, ash, and carbohydrate contents of sausages were determined according to the AOAC official methods [16].

2.4. Texture Profile Analysis. The sausages were prepared for analysis by boiling as mentioned above [15]. Textural properties were evaluated using the TA.XT Plus Texture Analyser (Stable Micro Systems, UK) as described [17]. Three central cores of $1 \mathrm{~cm}$ height and $2.5 \mathrm{~cm}$ diameter of each sausage were selected for analysis. The cores were compressed to $50 \%$ of their original height for two times using a $75 \mathrm{~mm}$ compression platen and $50 \mathrm{kgf}$ load cell. The compression parameters included a constant speed of $3.0 \mathrm{~mm} / \mathrm{s}$, test speed of $1.0 \mathrm{~mm} / \mathrm{s}$, posttest speed of $3.0 \mathrm{~mm} / \mathrm{s}$, and prefixed strain of $75 \%$. These tests were hardness (maximum force required to compress the sample), springiness (ability of the sample to recover its original form after the deforming force was removed), cohesiveness (extent to which the sample could be deformed prior to rupture), chewiness (work necessary to masticate the sample for swallowing), adhesiveness (the work necessary to overcome the attractive forces between the surface of a food and surface of other materials which it comes in contact with), and gumminess (the energy required to disintegrate a semisolid food to a state ready for swallowing) [18]. To improve the ease of core preparation, the analysis was performed at a uniform temperature of $20-21^{\circ} \mathrm{C}$ [19].

2.5. Sensory Analysis. The sensory analysis was conducted by eight untrained assessors in the sensory evaluation laboratory. The critical point of appraisal of meat quality occurs when the product is consumed and it is this outcome that determines the decision to repurchase $[20,21]$. The sausages were therefore prepared in a way that simulates sausage preparation by the consumer. Sausages, deep-fried in refined vegetable cooking oil $\left(150^{\circ} \mathrm{C}\right)$ for $5 \mathrm{~min}$ [22] and cooled for $15 \mathrm{~min}$, were cut into $1 \mathrm{~cm}$ cubes and served to each assessor. Five sensory attributes, appearance/colour, flavour, juiciness, tenderness, and overall acceptability, were evaluated. The interpretation of attributes was discussed among assessors prior to the taste sessions. Each attribute was scored using five-point hedonic scale ranging from 1 (disliked extremely) to 5 (liked extremely).

2.6. Statistical Analysis. The data were analysed using SPSS statistics package version 23 [23]. Means and standard deviations of nutritional and textural properties were computed for all samples and compared using one-way analysis of variance (ANOVA). Significant means $(P \leq 0.05)$ were separated using Duncan's mean separation technique. Pearson's correlation test $(P \leq 0.05)$ was used to determine relationship between nutritive and textural properties. The sensory properties were analysed using nonparametric Kruskal-Wallis one-way ANOVA $(P \leq 0.05)$. The stepwise-stepdown procedure was used to separate statistically significant categories (KruskalWallis, $P \leq 0.05$ ). Since the data obtained with five-point hedonic scale were not normally distributed, the ranking test was used to analyse it as recommended [24].

\section{Results}

3.1. Nutritional Properties. The nutritive content of sausages is shown in Table 1 . The mean percentage moisture content of the sausages was found to be $43.89 \pm 1.66 \%$, whereas the mean percentage protein, fat, ash, and carbohydrate contents were $9.82 \pm 2.71 \%, 22.37 \pm 1.7 \%, 2.99 \pm 0.10 \%$, and $20.94 \pm 3.05 \%$, respectively. The moisture, protein, fat, and ash content of the sausages differed statically with sampling day $(P<0.05)$ but carbohydrate content was statistically similar $(P>0.05)$.

3.2. Textural Properties. The data pertaining to textural properties of sausages are presented in Table 2. The mean values for hardness, adhesiveness, springiness, cohesiveness, and chewiness were $103.36 \pm 3.48 \mathrm{~N},-4.54 \pm 1.58 \mathrm{~N} \mathrm{~s}, 3.38 \pm$ $0.67 \mathrm{~mm}, 0.15 \pm 0.03,16.07 \pm 3.20 \mathrm{~N}$, and $55.73 \pm 20.44 \mathrm{~N} \mathrm{~mm}$, respectively. Hardness and springiness were highest in Day 3 
TABLE 1: Percentage of proximate composition of rabbit sausages.

\begin{tabular}{lccccc}
\hline Sampling day & Moisture & Protein & Fat & Ash $^{\mathrm{h}}$ & $\mathrm{CHO}^{\dagger}$ \\
\hline Day 1 & $45.37 \pm 0.86^{\mathrm{b}}$ & $12.06 \pm 1.35^{\mathrm{b}}$ & $20.45 \pm 1.15^{\mathrm{a}}$ & $2.89 \pm 0.07^{\mathrm{a}}$ & $18.97 \pm 1.36^{\mathrm{a}}$ \\
Day 2 & $44.91 \pm 1.08^{\mathrm{ab}}$ & $11.47 \pm 1.38^{\mathrm{b}}$ & $21.44 \pm 1.02^{\mathrm{a}}$ & $2.97 \pm 0.06^{\mathrm{ab}}$ & $19.16 \pm 2.17^{\mathrm{a}}$ \\
Day 3 & $42.04 \pm 1.12^{\mathrm{a}}$ & $6.96 \pm 1.73^{\mathrm{a}}$ & $24.44 \pm 0.59^{\mathrm{b}}$ & $3.1 \pm 0.07^{\mathrm{b}}$ & $23.62 \pm 2.21^{\mathrm{a}}$ \\
Day 4 & $43.25 \pm 0.89^{\mathrm{ab}}$ & $8.7 \pm 2.39^{\mathrm{ab}}$ & $23.05 \pm 0.97^{\mathrm{ab}}$ & $2.92 \pm 0.02^{\mathrm{a}}$ & $21.99 \pm 3.22^{\mathrm{a}}$ \\
\hline
\end{tabular}

Mean $\pm \mathrm{SD}, n=3$.

Values with different superscript letters within a column were statistically different $(P<0.05)$ according to Duncan test.

${ }^{\dagger}$ Carbohydrate.

TABLE 2: Textural properties of commercial rabbit sausages.

\begin{tabular}{lcccccc}
\hline Sampling day & Hardness (N) & Adhesiveness (N s) & Springiness (mm) & Cohesiveness (ratio) & Gumminess (N) & Chewiness (N mm) \\
\hline Day 1 & $98.42 \pm 0.87^{\mathrm{a}}$ & $-4.17 \pm 0.05^{\mathrm{c}}$ & $3.23 \pm 0.12^{\mathrm{b}}$ & $0.13 \pm 0.02^{\mathrm{a}}$ & $12.55 \pm 1.39^{\mathrm{a}}$ & $40.59 \pm 4.24^{\mathrm{a}}$ \\
Day 2 & $102.61 \pm 0.84^{\mathrm{b}}$ & $-2.13 \pm 0.12^{\mathrm{d}}$ & $2.50 \pm 0.08^{\mathrm{a}}$ & $0.13 \pm 0.01^{\mathrm{a}}$ & $13.72 \pm 0.53^{\mathrm{a}}$ & $34.30 \pm 2.46^{\mathrm{a}}$ \\
Day 3 & $107.70 \pm 0.59^{\mathrm{c}}$ & $-6.17 \pm 0.05^{\mathrm{a}}$ & $4.37 \pm 0.05^{\mathrm{c}}$ & $0.18 \pm 0.01^{\mathrm{b}}$ & $19.55 \pm 0.65^{\mathrm{b}}$ & $85.38 \pm 2.90^{\mathrm{c}}$ \\
Day 4 & $104.72 \pm 0.95^{\mathrm{b}}$ & $-5.70 \pm 0.08^{\mathrm{b}}$ & $3.40 \pm 0.08^{\mathrm{b}}$ & $0.18 \pm 0.01^{\mathrm{b}}$ & $18.45 \pm 1.56^{\mathrm{b}}$ & $62.75 \pm 4.78^{\mathrm{b}}$ \\
\hline
\end{tabular}

Mean \pm SD, $n=3$.

Values with different superscript letters within a column were statistically different $(P<0.05)$ according to Duncan test.

while adhesiveness was highest in Day $2(P<0.05)$. Cohesiveness, gumminess, and chewiness were highest in Days 3 and $4(P<0.05)$.

All TPA parameters except adhesiveness showed significant positive correlation with fat and carbohydrate contents $(P<0.05$, resp. $)$ and negative correlation with moisture and protein contents $(P<0.05$, resp.). The ash content was positively correlated with hardness $(P<0.05)$. Moisture had highest while ash had the least correlation coefficients. The correlation coefficients and significance value $(P=0.05)$ of the nutritional and textual properties are shown in Table 3.

3.3. Sensory Properties. The sensory properties of the sausages are shown in Table 4. The mean ranking score for juiciness varied from 30.06 to 37.38 , tenderness from 26.75 to 40.69 , flavour from 29.41 to 35.91 , appearance/colour from 28.28 to 38.78 , and overall acceptability from 29.03 to 36.75. Of the total sensory parameters, only tenderness varied between samples collected at different time points $(P<0.05)$.

\section{Discussion}

Up to now, the interaction among properties of rabbit sausages had not been investigated. Rabbit meat processors therefore had to extrapolate these interactions in sausages or other processed meat products from other species, for example, poultry [5], despite the fact that meat differs from species to species to some extent. Therefore, technological and eating quality of resulting products from different meats is bound to differ. For that reason, rabbit meat processors may face a challenge of meeting the consumers' increasing demand of consistent eating quality. To provide the processors with empirical data the interaction of nutritive, textural, and sensory properties in rabbit sausages was studied.

The addition of water to meat products influences its textural and organoleptic properties [25]. The sausages samples evaluated presently had considerably lower moisture content than the approximate $63 \%$ reported in frankfurter sausages [25]. In this study, the highest correlation coefficient was observed for hardness (Table 3). Since hardness determines the commercial value of meat, decreased moisture content in rabbit sausage might reduce its acceptance [15]. This can affect future consumption of rabbit sausages.

The mean protein content in the rabbit sausages (Table 1) was lower than $14 \%$ normally observed in frankfurter sausages [25]. The low protein and moisture contents indicate fewer bound water molecules after cooking. This may explain similar effects of protein and moisture on TPA parameters observed in Table 3. Springiness (elasticity) and cohesiveness in meat products is attributed to gel formation of muscle proteins especially actin and myosin [12, 26, 27]. Thus, a positive correlation between protein content and the two parameters, springiness and cohesiveness, is expected. However, protein and moisture contents in the rabbit sausages were low and hence fewer water molecules available to form gel may explain absence of any correlations.

Fat is the most important nonmeat ingredient added to sausages. In frankfurter type sausages, the mean fat content is reported to be more than $20 \%$ [25,28]. The addition of extra high fat to frankfurter type sausages reduces or substitutes moisture and protein [29]. This explains the contrasting effects of high fat on the sausages' characteristics observed in this study compared with protein and moisture (Table 3). Nonetheless, the correlation coefficients between fat content and textural properties were lower than that of protein or moisture. This is in line with earlier observation that protein has a greater influence on texture than fat [30]. Nevertheless, the inverse relationship between fat and adhesiveness and direct relationship between fat and cohesiveness suggest the role of fat in improving water holding capacity (WHC) and texture of rabbit sausages, respectively. WHC is the fraction of the total water that is located between the filaments in myofibrils [31]. 
TABLE 3: Correlation coefficients and significance test $(P=0.05)$ of texture profile analysis parameters applied and nutritional properties of commercial rabbit sausages.

\begin{tabular}{|c|c|c|c|c|c|c|}
\hline \multirow{2}{*}{ Nutritional properties } & \multicolumn{6}{|c|}{ Textural properties } \\
\hline & Hardness (N) & Adhesiveness (N s) & Springiness (mm) & Cohesiveness (ratio) & Gumminess $(\mathrm{N})$ & Chewiness $(\mathrm{N} \mathrm{mm})$ \\
\hline Moisture & $-0.83^{* * *}$ & $0.69^{* *}$ & $-0.83^{* * *}$ & $-0.63^{* *}$ & $-0.71^{* *}$ & $-0.73^{* *}$ \\
\hline Protein & $-0.82^{* * *}$ & $0.70^{* *}$ & $-0.77^{* *}$ & $-0.57^{* *}$ & $-0.66^{* *}$ & $-0.67^{* *}$ \\
\hline Fat & $0.75^{* *}$ & $-0.64^{* *}$ & $0.74^{* *}$ & $0.52^{* *}$ & $0.55^{* *}$ & $0.66^{* *}$ \\
\hline Ash & $0.47^{* *}$ & $-0.18^{*}$ & $0.12^{*}$ & $0.26^{*}$ & $0.34^{*}$ & $0.25^{*}$ \\
\hline $\mathrm{CHO}^{\dagger}$ & $0.64^{* *}$ & $-0.58^{* *}$ & $0.73^{* *}$ & $0.44^{* *}$ & $0.54^{* *}$ & $0.58^{* *}$ \\
\hline \multicolumn{7}{|l|}{$\begin{array}{l}{ }^{* * *} P<0.001 . \\
{ }^{* *} P<0.05 . \\
{ }^{*} P>0.05 . \\
{ }^{\dagger} \text { Carbohydrate. }\end{array}$} \\
\hline $\begin{array}{l}\text { ABLE 4: The mean } \\
\text { ampling days given }\end{array}$ & $\begin{array}{l}\text { and statist } \\
\text { ruskal-Wall }\end{array}$ & $\begin{array}{l}\text { significance }(P= \\
H \text { test. }\end{array}$ & $0.05)$ of each of $t$ & ensory properties & ommercial ra & sausages from four \\
\hline Sampling day & Juiciness & Tenderness & Flavour & Appearance/ & colour & Overall acceptability \\
\hline Day 1 & 30.25 & $40.69^{\mathrm{b}}$ & 29.41 & 30.19 & & 30.56 \\
\hline Day 2 & 30.06 & $35.81^{\mathrm{ab}}$ & 30.88 & 28.28 & & 29.03 \\
\hline Day 3 & 32.31 & $26.75^{\mathrm{a}}$ & 35.91 & 32.75 & & 33.66 \\
\hline Day 4 & 37.38 & $26.75^{\mathrm{ab}}$ & 33.81 & 38.78 & & 36.75 \\
\hline Sig. $(P=0.05)$ & 0.59 & 0.04 & 0.70 & 0.34 & & 0.57 \\
\hline
\end{tabular}

Mean ranks, $n=8$.

Values with different superscript letters within a column were statistically different $(P<0.05)$ according to stepwise-stepdown procedure of Kruskal-Wallis $H$ test.

The ash content of rabbit meat varies from $1.23 \%$ to $1.36 \%$ and that of corn starch from $0.70 \%$ to $0.78 \%$ with manufacture $[32,33]$. The ash and starch contents in the rabbit sausages do not fully account for the ash content in rabbit sausages. The addition of other ingredients, salt (sodium chloride), during processing increases ash content of a product and influences textural properties of food $[17,34]$. In rabbit sausages, only hardness was significantly influenced by ash content (Table 3 ). The WHC of cooked sausages was reported to be in linear relationship with salt $(\mathrm{NaCl})$ when $2.0 \%$ to $2.5 \%$ of $\mathrm{NaCl}$ was used [35]. The maximum level of ash content (which is approximately $2.14 \%$ when considering maximum values of ash content in rabbit meat $(1.36 \%)$ and corn starch $(0.78 \%)[32,33])$ in the rabbit sausages, contributed by rabbit meat and corn starch, could have resulted in the low salt content in the sausages, thereby affecting WHC.

During cooking, high temperature induces structural and chemical changes in carbohydrates making meat more tender [25]. However, sausages evaluated through this study were harder though carbohydrate content was higher (Table 3). Starch binds water by physical entrapment and also forms complex with meat proteins (meat products containing both starch and protein) and after heating forms gel of greater strength and more stable emulsion than those with only proteins $[25,36]$. Therefore, water is an important component required for gel formation. Low moisture content in sausages studied presently indicates that less water was available to interact with the starch thereby affecting the gel forming process. This perhaps might have accelerated the retrogradation of starch and made sausages harder.
The consumer acceptance of quality elements such as tenderness, juiciness, and flavour of meat is the major determinant of meat quality [37]. The organoleptic parameter, juiciness, is dependent on the amount of moisture released from the meat and the degree of salivation induced during mastication [38]. The water content makes products juicy and makes it easily chewable [25]. The negative effect of low moisture content on the quality of rabbit sausages was evident from the low scores of juiciness and tenderness (Table 4). Sausages from Days 1 and 2 had the least moisture content and at the same time had least mean ranks of both juiciness and tenderness.

Flavour in meat products is a function of the interaction of the fats, proteins, and salt present and their proportions in the meat product. Therefore, the low flavour scores of rabbit sausages observed here may be due to the effect of low protein and salt contents (Table 4). The Maillard reaction between amino acids and reducing sugars and thermal degradation of lipids are responsible for flavour of red meats [39]. On the other hand, salt acts as a flavour enhancer and increases characteristic flavour of meat products [40]. The low flavour scores were observed despite the fact that high fat content usually improves sensory attributes [41]. The higher correlation coefficients of protein and moisture than fat observed in Table 3 may have resulted in the low scores.

Lightness or appearance, a colour parameter, is a main attribute that correlates well with consumer acceptance $[15$, 42]. Frankfurters become lighter and less reddish in colour as fat level increases [30]. High fat content without a corresponding increase in protein content might have made the 
sausages lighter and without the characteristic red hue of meat that is expected in sausages. This may have contributed to a low appeal among the consumers.

\section{Conclusion}

Moisture, protein, fat, and carbohydrate contents significantly influenced textural properties of rabbit sausages. However, moisture and protein contents had the largest correlation coefficients. Low contents of these two ingredients resulted in hard sausages with low sensory panellist acceptance. To improve rabbit sausages, it is recommended that processors develop an optimal rabbit sausage formulation. This would include addition of more water and rabbit meat and less of corn starch and rusk. The amount of ingredients in their formulation is fundamental to realizing such a formulation. The processors should aim at achieving high sensory scores for tenderness, juiciness, and flavour, which were observed to influence panellists' acceptance of rabbit sausages the most.

\section{Competing Interests}

The authors declare no competing interests.

\section{Acknowledgments}

The authors would like to thank the National Council for Science, Technology and Innovation, Kenya, for financing the research.

\section{References}

[1] A. Muthee, "Kenya livestock sector study: An analysis of pastoralist livestock products market value chains and potential external markets for live animals and meat," 2006, http://pdf.usaid .gov/pdf_docs/pnady825.pdf.

[2] C. L. Delgado, "Rising consumption of meat and milk in developing countries has created a new food revolution," Journal of Nutrition, vol. 133, supplement 2, no. 11, pp. 3907S-3910S, 2003.

[3] S. Lukefahr and P. Cheeke, "Rabbit project development strategies in subsistence farming systems," World Animal Review, vol. 68, pp. 60-70, 1991.

[4] C. Cavani, M. Petracci, A. Trocino, and G. Xiccato, "Advances in research on poultry and rabbit meat quality," Italian Journal of Animal Science, vol. 8, no. 2, pp. 741-750, 2009.

[5] M. Petracci and C. Cavani, "Trends in rabbit meat processing," in Proceedings of the 10th World Rabbit Congress, pp. 851-858, Sharm El-Sheikh, Egypt, September 2012.

[6] A. Dalle Zotte, "Perception of rabbit meat quality and major factors influencing the rabbit carcass and meat quality," Livestock Production Science, vol. 75, no. 1, pp. 11-32, 2002.

[7] N. Kondaiah, "Value added meat products and development of processed meat sector," Natural Product Radiance, vol. 3, pp. 281-283, 2004.

[8] A. H. Deogade, P. N. Zanjad, and M. Raziuddin, "Value added meat products," Veterinary World, vol. 1, no. 3, pp. 88-89, 2008.

[9] K. Grunert, "How changes in consumer behaviour and retailing affect competence requirements for food producers and processors," Economia Agraria y Recursos Naturales, vol. 6, no. 11, pp. 3-22, 2006.
[10] J. Codron, K. Grunert, E. Giraud-heraud, L. Soler, and A. Regmi, "Retail sector responses to changing consumer preferences: the european experience," in New Directions in Global Food Markets, A. Regmi and M. Gehlhar, Eds., pp. 32-46, US Department of Agriculture, 2003.

[11] Ö. Parlak, Ö. Zorba, and Ş. Kurt, "Modelling with response surface methodology of the effects of egg yolk, egg white, and sodium carbonate on some of the physical-chemical and sensory properties of beef patties," International Journal of Food Engineering, vol. 7, no. 2, pp. 1-13, 2011.

[12] Ö. Parlak, Ö. Zorba, and Ş. Kurt, "Modelling with response surface methodology of the effects of egg yolk, egg white and sodium carbonate on some textural properties of beef patties," Journal of Food Science and Technology, vol. 51, no. 4, pp. 780784, 2014.

[13] J. Lorenzo and D. Franco, "Influence of fat level on physicochemical, textural and sensory attributes of dry-cured duck 'salchichón”,' Focusing on Modern Food Industry, vol. 2, no. 2, pp. 70-77, 2013.

[14] A. Yousefi and M. Moosavi-Nasab, "Textural and chemical attributes of minced fish sausages produced from Talang Queenfish (Scomberoides commersonnianuus) minced and surimi," Iranian Journal of Fisheries Sciences, vol. 13, no. 1, pp. 228-241, 2014.

[15] N. Huda, L. H. Wei, A. T. L. Jean, and I. Ismail, "Physicochemical properties of Malaysian commercial chicken sausages," International Journal of Poultry Science, vol. 9, no. 10, pp. 954-958, 2010.

[16] AOAC, Official Methods of Analysis of the AOAC International, AOAC International, Gaithersburg, Maryland, 18th edition, 2006.

[17] N. Huda, T. L. J. Alistair, H. W. Lim, and R. Nopianti, "Some quality characteristics of Malaysian commercial fish sausage," Pakistan Journal of Nutrition, vol. 11, no. 8, pp. 700-705, 2012.

[18] M. Bourne, Food Texture and Viscosity: Concept and Measurement, Academic Press, Waltham, Mass, USA, 2002.

[19] W. R. Caine, J. L. Aalhus, D. R. Best, M. E. R. Dugan, and L. E. Jeremiah, "Relationship of texture profile analysis and Warner-Bratzler shear force with sensory characteristics of beef rib steaks," Meat Science, vol. 64, no. 4, pp. 333-339, 2003.

[20] S. J. Boleman, S. L. Boleman, R. K. Miller et al., "Consumer evaluation of beef of known categories of tenderness," Journal of Animal Science, vol. 75, no. 6, pp. 1521-1524, 1997.

[21] W. Verbeke and J. Viaene, "Beliefs, attitude and behaviour towards fresh meat consumption in Belgium: empirical evidence from a consumer survey," Food Quality and Preference, vol. 10, no. 6, pp. 437-445, 1999.

[22] K.-W. Lin and J.-Y. Chao, "Quality characteristics of reduced-fat Chinese-style sausage as related to chitosan's molecular weight," Meat Science, vol. 59, no. 4, pp. 343-351, 2001.

[23] IBM Corporation, IBM SPSS Statistics 20 Documentation, 2015.

[24] E. McCrum-Gardner, "Which is the correct statistical test to use?" British Journal of Oral and Maxillofacial Surgery, vol. 46, no. 1, pp. 38-41, 2008.

[25] G. Heinz and P. Hautzinger, Meat Processing Technology for Small-to Medium-Scale Producers, Food and Agriculture Organization of the United Nations, Rome, Italy, 2007.

[26] F. G. Daros, M. L. Masson, and S. C. Amico, "The influence of the addition of mechanically deboned poultry meat on the rheological properties of sausage," Journal of Food Engineering, vol. 68, no. 2, pp. 185-189, 2005. 
[27] E. Niwa, “Chemistry of gelation," in Surimi Technology, T. C. Lanier and C. M. Lee, Eds., pp. 389-428, Marcel Dekker Inc, New York, NY, USA, 1992.

[28] J. T. Keeton, "Low-fat meat products-technological problems with processing," Meat Science, vol. 36, no. 1-2, pp. 261-276, 1994.

[29] E. Cengiz and N. Gokoglu, "Effects of fat reduction and fat replacer addition on some quality characteristics of frankfurtertype sausages," International Journal of Food Science and Technology, vol. 42, no. 3, pp. 366-372, 2007.

[30] E. D. Paneras, J. G. Bloukas, and S. N. Papadima, "Effect of meat source and fat level on processing and quality characteristics of frankfurters," LWT-Food Science and Technology, vol. 29, no. 5-6, pp. 507-514, 1996.

[31] G. Offer and J. Trinick, "On the mechanism of water holding in meat: the swelling and shrinking of myofibrils," Meat Science, vol. 8, no. 4, pp. 245-281, 1983.

[32] A. Dal Bosco, Z. Szendrö, Z. Matics et al., "Effect of floor type on carcass and meat quality of pen raised growing rabbits," World Rabbit Science, vol. 23, no. 1, pp. 19-26, 2015.

[33] E. I. Yousif, M. G. E. Gadallah, and A. M. Sorour, "Physicochemical and rheological properties of modified corn starches and its effect on noodle quality," Annals of Agricultural Sciences, vol. 57, no. 1, pp. 19-27, 2012.

[34] A. Saint-Eve, C. Lauverjat, C. Magnan, I. Déléris, and I. Souchon, "Reducing salt and fat content: impact of composition, texture and cognitive interactions on the perception of flavoured model cheeses," Food Chemistry, vol. 116, no. 1, pp. 167-175, 2009.

[35] M. Ruusunen, J. Vainionpää, M. Lyly et al., "Reducing the sodium content in meat products: the effect of the formulation in low-sodium ground meat patties," Meat Science, vol. 69, no. 1, pp. 53-60, 2005.

[36] D. Petridis, E. Vlazakis, I. Tzivanos, E. Derlikis, and C. Ritzoulis, "Effects of selected ingredients and fat content on the sensory and mechanical properties of frankfurter-type sausages," Journal of Texture Studies, vol. 41, no. 6, pp. 880-898, 2010.

[37] C. Maltin, D. Balcerzak, R. Tilley, and M. Delday, "Determinants of meat quality: tenderness," Proceedings of the Nutrition Society, vol. 62, no. 2, pp. 337-347, 2003.

[38] R. A. Lawrie and D. Ledward, Lawrie's Meat Science, Elsevier Science and Technology, Cambridge, UK, 7th edition, 2012.

[39] N. Scollan, J.-F. Hocquette, K. Nuernberg, D. Dannenberger, I. Richardson, and A. Moloney, "Innovations in beef production systems that enhance the nutritional and health value of beef lipids and their relationship with meat quality," Meat Science, vol. 74, no. 1, pp. 17-33, 2006.

[40] M. Ruusunen, M. Simolin, and E. Puolanne, "The effect of fat content and flavor enhancers on the perceived saltiness of cooked 'bologna-type' sausages," Journal of Muscle Foods, vol. 12, no. 2, pp. 107-120, 2001.

[41] C. Ritzoulis, D. Petridis, E. Derlikis, K. Fytianos, and P. Asteriou, "Utilization of inverse water-in-oil emulsions as fat replacers in frankfurter model sausages: influence of fat emulsion content on the organoleptic and mechanical properties," Journal of Texture Studies, vol. 41, no. 1, pp. 62-74, 2010.

[42] G. I. Dingstad, E. Kubberød, T. Næs, and B. Egelandsdal, "Critical quality constraints of sensory attributes in frankfurtertype sausages, to be applied in optimization models," LWTFood Science and Technology, vol. 38, no. 6, pp. 665-676, 2005. 

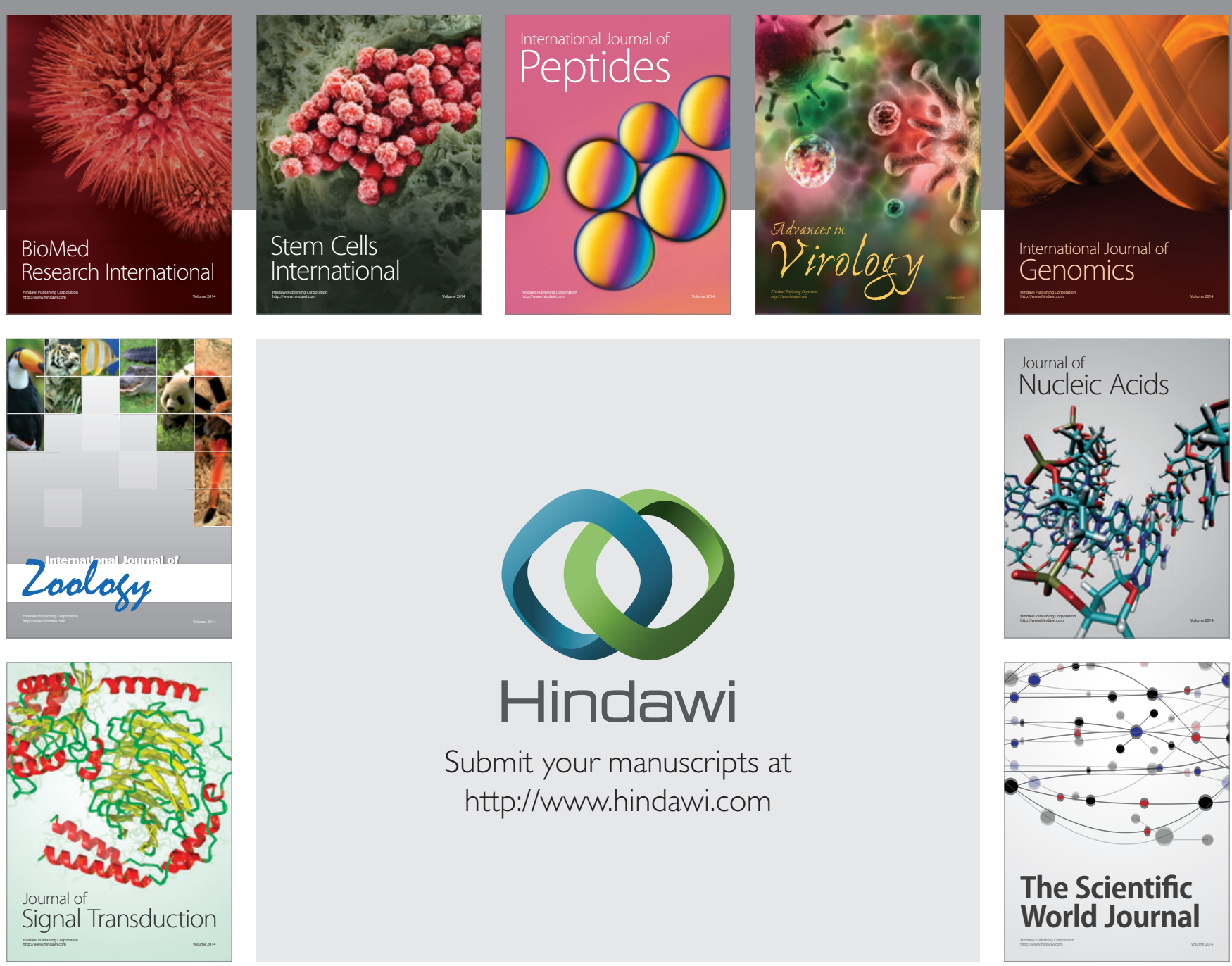

Submit your manuscripts at

http://www.hindawi.com
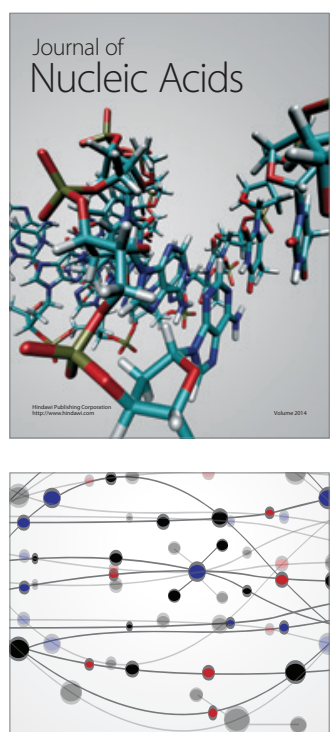

The Scientific World Journal
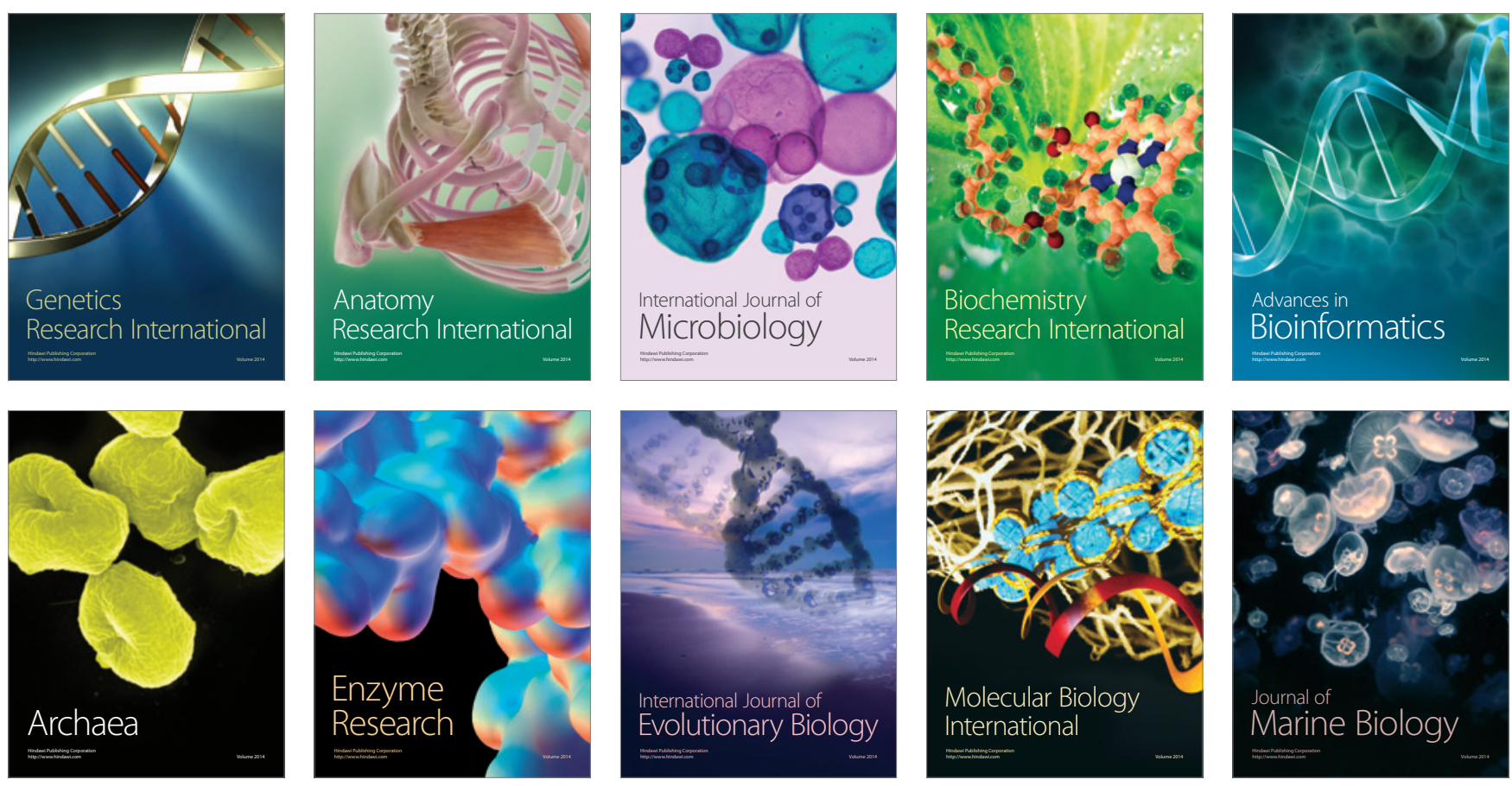